\title{
RESENHA
}

\section{A ATIVIDADE EDUCATIVA DOS JESUÍTAS NO JAPÃO (1549-1597)}

\author{
Daniel Longhini Vicençoni ${ }^{1}$ \\ Renata Franqui2
}

FUTATA, Marli Delmonico de Araujo. Os jesuítas no Japão (1549-1597): os desafios da missão numa sociedade letrada. Curitiba: CRV, 2020. 191 p.

A obra intitulada "Os jesuítas no Japão (1549-1597): os desafios da missão numa sociedade letrada", foi escrita pela professora e pesquisadora Marli Delmônico de Araújo Futata. Inicialmente, o texto foi apresentado, em 2018, ao Programa de Pós-Graduação em Educação da Universidade Estadual de Maringá, como um dos requisitos para obtenção do título de doutora em Educação. Em 2020 a tese foi publicada pela editora CRV.

Marli Delmônico de Araújo Futata, é graduada em Pedagogia (1994), mestra em Educação (2008) e doutora em Educação (2018) pela Universidade Estadual de Maringá. Atualmente é professora adjunta da Universidade Estadual de Maringá, lotada no Departamento de Pedagogia Campus Regional de Cianorte.

\footnotetext{
1 Aluno de Doutorado do Programa de Pós-graduação em Educação da Universidade Estadual de Maringá, na linha de pesquisa em História e Historiografia da Educação. Participa do Grupo de Pesquisa Sobre Política, Religião e Educação na Modernidade Universidade Estadual de Maringá (UEM), Maringá, PR, Brasil. Orcid iD: https://orcid.org/00000003-3662-8855. E-mail: daniel.longhini97@gmail.com

2 Aluna de Doutorado do Programa de Pós-graduação em Educação da Universidade Estadual de Maringá, na linha de pesquisa em História e Historiografia da Educação. Participa do Grupo de Pesquisa Sobre Política, Religião e Educação na Modernidade Universidade Estadual de Maringá (UEM), Maringá, PR, Brasil. Orcid iD: https://orcid.org/00000002-1210-4558. E-mail: renata.franqui@hotmail.com
} 
O livro possui sete divisões: 1) Prefácio; 2) Prólogo; 3) Introdução; 4) Capítulo 1, A Companhia de Jesus e os fundamentos da educação jesuítica; 5) Capítulo 2, O Japão do século XVI e a recepção do catolicismo; 6) Capítulo 3, Missão e educação jesuítica entre os japoneses; 7) Conclusão.

Trata-se de uma obra que seguiu com rigor as exigências do campo da História da Educação, tendo como método de análise o da Ciência da História. Além disso, no decorrer da escrita, é possível verificar que o conceito de Educação não se restringiu à educação formal, mas, a todo o processo de transmissão de saber entre os humanos.

No prefácio, o professor doutor Flavio Massami Martins Ruckstadter (PPEd/UENP) destaca que a obra apresenta um vasto corpo documental, fruto das pesquisas em arquivos, especialmente de Portugal, realizado pela autora. O trabalho de levantamento das fontes permitiu que a tese fosse desenvolvida.

No prólogo, escrito pelo professor doutor Oriomar Skalinski Junior (DEED/UEPG), vemos o destaque da importância do livro para História e Historiografia da Educação no Brasil, uma vez que apresenta aos leitores, informações relevantes sobre a atuação da Companhia de Jesus, no Japão, no século XVI, cujo início coincidiu com a chegada dos jesuítas à América portuguesa.

O capítulo um, intitulado A Companhia de Jesus e os fundamentos da educação jesuítica, apresenta um aprofundamento teórico a respeito do conceito de Educação, com ênfase para o elo entre as práticas sociais e o agir educativo. Para além das definições, a autora analisou o contexto histórico da fundação dos Jesuítas, ressaltando a importância do padre fundador, Inácio de Loyola (1491-1556), para o sucesso precoce da Ordem. Afirmou também, a importância do humanismo cristão como fundamento da ação educativa dos religiosos da Companhia de Jesus e reforçou seu argumento com uma discussão pertinente acerca da Ratio Studiorum, cuja primeira edição de 1599, influenciou decisivamente toda a prática pedagógica da Companhia de Jesus. 
No segundo capítulo, O Japão do século XVI e a recepção do catolicismo, a autora analisa historicamente o Japão no século XVI, destacando as crenças religiosas da cultura japonesa e o contraste com a cultura cristã ocidental. O primeiro grupo de missionários da Companhia de Jesus que chegou ao território japonês foi liderado por Francisco Xavier (1506-1522), considerado pela historiografia um personagem basilar da história dos Jesuítas. As atividades dos missionários se fundamentaram em batizar a população local, organizar administrativamente a Ordem e a introdução do catolicismo na cultura japonesa. As dificuldades encontradas pelos Jesuítas eram variadas, sobretudo pelo choque cultural. Sem usar catecismos ou livros de espiritualidade católica, muitos missionários consideraram a atividade demasiadamente difícil. A população japonesa, já letrada, possuía suas próprias crenças, vinculadas, naquele período, ao Xintoísmo, Budismo e Confucionismo. A dinâmica das relações estabelecidas entre os lusitanos e japoneses se consolidou em meio a conflitos e disputas culturais e religiosas, logo no início das atividades missionárias.

O terceiro e último capítulo, intitulado Missão e educação jesuítica entre os japoneses, expõe as estratégias adotadas pelos Jesuítas em suas atividades pedagógicas, bem como a fundação e a administração de seminários e colégios no Japão. A presença da Companhia de Jesus no Japão, ainda na segunda metade do século XVI e seu trabalho na conversão dos japoneses à fé católica foi marcada por uma questão comum às duas culturas: o conhecimento da escrita e da leitura. Todas as estratégias utilizadas pelos padres foram baseadas na premissa de que os japoneses eram letrados, assim, constata-se que eles conheciam sua própria cultura religiosa, amplamente difundida por livros. A cultura letrada dos japoneses representou um desafio para os Jesuítas, pois, até mesmo as mulheres eram letradas e com isso, a divulgação da fé cristã em oposição às profissões de fé orientais, tornava-se difícil. Entre as medidas tomadas pelos membros da Companhia de Jesus, destacou-se a fundação das instituições educacionais, a exemplo do Noviciado de Usuki, dos seminários de Arima e Myako e do Colégio de Nagasaki, que foram essenciais na atividade 
educacional dos jesuítas que, em meio século, conseguiram propagar os preceitos católicos aos japoneses.

A conclusão da autora, após análise das diversas fontes documentais, demonstrou que o acesso à cultura letrada por parte dos japoneses influenciou diretamente a política missionária e educativa dos Jesuítas, pois as estratégias adotadas pelos padres da Ordem partiram, especialmente, dessa premissa.

Os Jesuítas, Ordem fundada em 1534, foram fundamentais no campo da Educação, no alvorecer da modernidade. As instituições educativas fundadas pelos padres são referência para as experiências educacionais que foram adotadas durante os séculos seguintes pela Companhia de Jesus.

A obra Os jesuítas no Japão (1549-1597): os desafios da missão numa sociedade letrada, é uma importante contribuição para a área da História e Historiografia da Educação, uma vez que apresenta uma análise crítica, baseada em um vasto número de fontes primárias, da atuação dos padres da Companhia de Jesus no Japão, no contexto do século XVI, especialmente pelo fato de que a ação missionária desses padres, utilizava estratégias diferentes daquelas comuns na América portuguesa. No entanto, em que pese tais distinções, eram também utilizadas as mesmas práticas devocionais e pastorais. Pela ausência de pesquisas sobre a temática, o livro, aqui apresentado, torna-se uma leitura fundamental àqueles que desejam aprofundar as discussões sobre os Jesuítas e suas contribuições para o campo da Educação.

Recebida em: 27 de maio de 2021.

Aprovada em: 27 de julho de 2021.

Publicada em: 04 de agosto de 2021. 
